Vladan Pavlović ${ }^{\star}$, Srećko Milačić ${ }^{\star *}$, Isidora Ljumović ${ }^{\star \star \star}$ * University of Pristina, Faculty of Economics (Kosovska Mitrovica)

${ }^{* *}$ University of Pristina, Faculty of Economics (Kosovska Mitrovica)

${ }^{\star \star \star}$ Economics Institute, Belgrade

\title{
Controversies about the Accounting Treatment of Transfer Fee in the Football Industry ${ }^{1}$
}

UDC: $339.72 ; 796.332 .071 .2: 347.4$

DOI: 10.7595/management.fon.2014.0001

Investments in sportsmen traditionally were considered as costs, together with transfer fees. From the second half of the twentieth century transfer fees are considered as assets. However, in the late twentieth and early twenty-first centuries the opinion prevailed that requirements for capitalization are met, and that capitalization and disclosure as intangibles are an obligatory procedure in almost all countries with a developed accounting tradition. There is the question of justification of the above procedure, having in mind that the contribution of the contracted fee for transfers cannot be determined related to the financial benefit of clubs, that players are often alienated before the end of the contract, and that the requirements for the control cannot be fully met.

Keywords: accounting policy, transfer fee, registration value, football industry

\section{Introduction}

The transfer fee represents a compensation for the termination of a contract, due to a player's transfer to a new club. This compensation payment is made by the new club, and it stands for the cost of acquiring. Transfer is possible only with the approval of the player, both clubs and football association. Therefore, transfer enables the relocation of players registration from one club to another. According to the Club Licensing Regulation of the Football Association of Serbia, the transfer fee is defined as 'the players registration value' (Regulatins/Pravilnik FSS). The concept of the player's transfer was established in England after the Football Association of England introduced the registration of players in the 1880s. Until the Bosman verdict, in 1995, a fee for players was also paid to players after the end of their contract. In the past few years, there has been a constant increase of transfer fee value, and having in mind the amount, it is not surprising that there is a great public interest in this issue.

Table 1. List of top 25 transfers in the $2010-11$ football season

\begin{tabular}{|c|l|l|l|l|}
\hline No. & Football player & From club & To club & Value \\
\hline \hline 1 & Fernando Torres & Liverpool & Chelsea & $58,500,000$ \\
\hline 2 & Andy Carroll & Newcastle & Liverpool & $41,000,000$ \\
\hline & David Villa & Valencia & FC Barcelona & $40,000,000$ \\
\hline & Wolfsburg & Manchester City & $37,000,000$ \\
$\epsilon$ & Edin Dzeko & Benfica & Real Madrid & $33,000,000$ \\
\hline 5 & Angel Di Maria & FC Barcelona & Manchester City & $30,000,000$ \\
\hline 6 & Yaya Touré & Internazionale & Manchester City & $29,500,000$ \\
\hline 7 & Mario Balotelli & Valencia & Manchester City & $28,750,000$ \\
\hline 8 & David Silva & Ajax & Liverpool & $26,500,000$ \\
\hline 9 & Luis Suarez & Benfica & Chelsea & $25,000,000$ \\
\hline 10 & David Louiz & &
\end{tabular}

${ }^{1}$ This paper is a part of the results of the research on Project 179001 supported by the Ministry of Education and Science of the Republic of Serbia 


\begin{tabular}{|c|l|l|l|l|}
\hline No. & Football player & From club & To club & Value \\
\hline \hline 11 & Aleksandar Kolarev & Lázio & Manchester City & $22,700,000$ \\
\hline 12 & Ramires & Benfica & Chelsea & $22,000,000$ \\
\hline 13 & Yoann Gourcouff & Bordeaux & Olimpique Lyon & $22,000,000$ \\
\hline 14 & James Milner & Aston villa & Manchester City & $22,000,000$ \\
\hline 15 & Bruno Alves & FC Porto & Zenith St. Petersberg & $22,000,000$ \\
\hline 16 & Darrent Bent & Sunderland & Aston Villa & $21,500,000$ \\
\hline 17 & Javier Marcherano & Liverpool & FC Barcelona & $20,000,000$ \\
\hline 18 & Carlos Eduardo & Hoffenheim & Rubin Kazan & $20,000,000$ \\
\hline 19 & Giampaolo Pazzini & Samdoria & Internazionale & $19,000,000$ \\
\hline 20 & Andrea Ranocchia & Genova & Internazionale & $18,500,000$ \\
\hline 21 & Robinho & Manchester City & AC Milan & $18,000,000$ \\
\hline 22 & Mesut Ozil & Werder Bremen & Real Madrid & $18,000,000$ \\
\hline 23 & Luis Gustavo & Hoffenheim & Bayern Munique & $17,000,000$ \\
\hline 24 & André-Pierre Gignac & Toulouse & Olimpique Marseille & $16,000,000$ \\
\hline 25 & Asomoah Gyan & Rennes & Sunderland & $16,000,000$ \\
$\epsilon$ \\
\hline
\end{tabular}

Source: Rearranged according to: Rosdet Nascimento, T. (2012).

It is much more cost-efficient for a club to hire players without contracts, because transfer fees are excluded. Although this is a case, even with top players ${ }^{2}$, it is still a rarity. Transfers from youth clubs, or signing new contracts with players after the end of their contracts are much more common. ${ }^{3}$

However, enormous transfer fees of top players, from time to time, can be very profitable for some clubs, primarily as a result of marketing effects. These transfers constantly attract media, football fans and a wider audience attention, leading to the increase of TV broadcast rights and commercial revenues. Also, they attract new sponsors, and finally, increase profits. The example of FC Real Madrid best illustrates the above-mentioned. One of the promises Florentino Perez made when he ran for president of Real Madrid in the 2000 elections, was that he would buy a high-priced star each year. He kept the promise and brought Luis Figo ${ }^{4}$, Zinəddin Lyazid Zidan ${ }^{5}$ and Ronaldo ${ }^{6}$. (According to: Bourgoies, 2007, p. 6).

\section{Accounting treatment of transfer fees}

As pointed out by Rowbottom, Accounting for transfer fees forms the most controversial area in football industry financial reporting "The accounting treatment of transfer fees depends upon whether player registrations are recognized as assets... Where registrations are viewed as assets, transfer fees are regarded as the acquisition costs. Where registrations are not viewed as assets, transfer fees are treated as expenses of the period." (Rowbottom, 1998, p. 110)

Capitalization of transfer fees, i.e. their recognition as intangible assets, together with their depreciation, for the first time was adopted by the Milwaukee Braves Basketball Club in 1963 (Flamholtz, 1985. According to: Rowbottom, 1998, p. 262). Flamholtz states that tax purpose is the main motive for this procedure (Rowbottom, 1998). In the USA, the identification and recognition of player registrations as intangible assets is common in basketball, American football, and hockey (Rowbottom, 1998).

\footnotetext{
${ }^{2}$ For example, the best German football player, Michael Ballack, joined FC Chelsae without transfer fee, because his contract with FC Bayern München had ended. He was later hired by Bayer 04 Leverkusen also without any transfer fees.Serbia

${ }^{3}$ We should here give na example of an Argentinian football player Lionel Andrés Messi Cuccitini who is one of the highest-paid players in the world. Messi has been playing for FC Barcelona since 2000, when he came to Europe, from Argentina.

${ }^{4}$ Transfer to Real in 2000: $€ 60$ million

${ }^{5}$ Transfer to Real in 2001: $€ 73,5$ million

${ }^{6}$ Transfer to Real in 2009: € 94 million
} 
In Europe, until the transfer fee capitalization was mandated, only a small number of clubs opted for this procedure. The research conducted in England in 1996, showed that $89 \%$ of clubs treated transfer fees as expenditures. The percentage of clubs that applied the process of capitalization grew from 1991 to 1995 (4\%, $9 \%, 8 \%, 13 \%, 16 \%$ respectively). However, it appears to have been halted in 1996 possibly due to the Bosman Ruling. (According to Rowbottom, 1998, p. 115)

At that time, there were different methods of registration accounting in England, because the subject matter was not clearly defined. ${ }^{7}$ Accordingly, the majority of clubs treated transfer fees as expenses of the period when the registration of players was signed, which exemplified a traditional accounting procedure. However, one group considered expenses as operating expenses, while others considered them as exceptional expenses. Some clubs recognized the registration value as intangible assets, and the recognition of registration value as current assets was recorded as well. Among the clubs that recognized the registration value as intangible assets, some clubs capitalized only transfer fees increased by agents' fees. Others presented the entire registration value in financial reports together with the registration of players with transfer fees, and registration of players who were transferred from youth clubs, as well as other players without transfer fees. It should be mentioned that at that time, before the Bosman verdict, clubs laid claim for transfer fees of both profiles of players, ones with contracts and those without contracts. Also, the matter of a player's value has been of great importance, especially for clubs that disclosed both registration value and players value in their financial reports. The practice of the players evaluation also differed. As mentioned by Dobbins and Trussell, the valuation of football player registrations was, for the first time, undertaken in the UK in 1975. Human resource accounting techniques were used to estimate the value of players' registrations held by Liverpool football club. (According to Rowbottom, 1998, p. 266) Later, Morrow developed a method used in the UEFA for the valuation of players without contracts in case of any disputes (this method applied to all of the judgment until the case of Bosman). The majority of clubs valuated the registration of players as transfer fees. However, some clubs have been valuing players in financial reports at their insurance value. (Rowbottom, 1998, p. 257)

Unlike the practice in England, transfer fees were presented as prepaid expenses in France, and as expenses of the period in Socialist Federal Republic of Yugoslavia.

Only after FRS10 - Goodwill and intangible assets came into force in December 1998, did the process of capitalization of transfer fees become mandatory in England (Amir \& Livne, 1995, p. 549). Passing the FRS 10 was soon followed by the IAS 38 - intangible assets. In France in 2004, the National Accounting Council (Conseil National de la Compatibilité) also made the capitalization of these expenditures mandatory for football clubs. (According to Gumb \& Demoulins-Lebault, 2010, p. 5) Nowadays, the process of capitalization of transfer fees is mandatory in many countries ${ }^{8}$. Amortization begins with the registration of a player and is calculated during the contractual period. If the contract is prolonged, the initial amortization plan is edited. In accordance with the imparity principle, the capitalized values are annually reviewed and, if necessary, their devaluation is performed. In case of 'selling a player with a contract' the difference between the registration value that is not depreciated and the transfer fees is considered a capital gain, i.e. loss. The consequence of presenting players as intangible assets is that "players themselves are the largest funds, with a tendency to constantly increase the share of total assets." (Pavlović, Mijatović, Milačić, 2013, p.60)

\section{Review of the justification of transfer fee capitalization}

The unification of the accounting treatment of transfer fees does not end the discussion about this issue. It is impossible to consider the justification of the accepted accounting policy without a thorough discussion, because there are many different aspects of registration value.

If a club has an intention to sell a player before the end of the contract, (before the Bosman verdict and after that period) which is a prevailing practice, the registration value can be considered as a club's asset, which is intended for resale. The reason is that the cub will earn transfer fees by selling a player. Namely, if the reg-

${ }^{7}$ The subject matter was defined in England by the The Companies Act in 1985 and standard SSAP 22, Accounting for Goodwill, [ASC, 1989] ${ }^{8}$ The mentioned treatment is also required by the UEFA Club Licensing and Financial Fair Play Regulations, and accordingly by the Club Licensing Regulation of the clubs of the Football Association of Serbia, for the competitions organised by the UEFA. 
istration of a player is viewed as an asset, it is a specific asset, since it is used in business, and during the time not only does its not lose its value but its value can grow. If we talk about clubs that create players, the expectations that the fees received on behalf of the transfer fees will surpass the paid fees for the transfer is not unreasonable, especially given the constant growth and value transfer. The above-mentioned represents a specific case for the accounting theory. The specificity should not come as a surprise, since a person is the core of the contract that is the subject of accounting treatment. Furthermore, if we look at the registration value as the club's asset, it is natural to also express the registration of players acquired through the transfer and registration of players acquired without transfer.

The key question is how to measure the registration of players if it is observed as described above. If the aim of the accounting treatment of registration is to give an insight into the financial position of the club, the historical cost is absolutely inappropriate for those purposes, for both players with and those without transfer fees. The cost of registration value of both young players and the players who improve their quality or become popular, is much lower that a potential transfer fee. On the other hand, the cost of the registration value for players who show poor performance and results, and especially those whose careers are bound to end soon, is higher than a potential transfer fee, if transfer is possible. In any case, a potential transfer fee will not be even close to the paid transfer fee (cost of registration value). Evaluation of the depreciation of this specific asset, in accordance with the imparity principle, can be done exclusively based on personal attitudes of the management. (see more in: Knežević et all, 2012)

An undervaluation of the cost of the registration value in relation to transfer fees is well illustrated in the following example: For the transfer of Ronaldo, Sporting CP paid €2,245 to Nacional de Madeira in 1997, (according to ), then Manchester United paid €17.5 million to Sporting in 2003, and later Real Madrid paid €94 million to Manchester United in 2009. (http://www.transfermarkt.de). Such exorbitance of the cost is exemplified in the cases of the Argentinian football player Verón and the Spanish football player Albert Luque Martos. Namely, for the transfer of Verón, Manchester United paid €42.6 million to Lazio in 2001, which was, at that time, the most expensive transfer in the history of football in England. Verón did not fit in into the Manchester team and he spent most of his time on the bench. In July 2003 he was transferred to Chelsae for the price of $€ 22.5$ million. (http://www.transfermarkt.de) However, Verón got injured after a really good start, so he played only fifteen games in the season 2003/2004. For the transfer of Albert Luque Martos Newcastle United has lost $€ 12$ million, and Ajax Amsterdam another $€ 7.5$ million. Martos barely played while he was in Ajax, he was fined and told to leave the club after the conflicts with his teammate Luis Suárez. (http://www.transfermarkt.de).

There are no rules concerning the value of transfer. This value for some players decreases even during their best performance, but later increases abruptly. The example of a French football player Valérien Ismaël is very illustrative. Namely, Crystal Palace brought Ismaël from Racing Straßburg for €3.8 million, which was the highest amount that this club has ever paid for a transfer. The player has spent ten months at this club, and played only in 13 games. Later he has been transferred to a French club RC Lens for $€ 1.8$ million. Therefore, the capital loss was $€ 2$ million. The next transfer of this very player was paid $€ 300,000$ when he was transferred from Racing Straßburg to SV Werder Bremen in 2003. After the participation in the championship league, he was transferred from Verder to Bayern München for $€ 8.5$ million. Therefore, the capital gain was $€ 8.2$ million. (http://www.transfermarkt.de)

In a nutshell, we can say that there is a general consensus that the cost of the registration value does not correspond to a potential transfer fee, so the advocates of this thesis suggest a replacement value as more trustworthy. (Quirk and Fort, 1992, Rowbottom, 2002 and others) As pointed out by Quirk and Fort and invoked by Rowbottom, (Rowbottom, 2002, p. 255) a player's replacement value can be ascertained based on transfer fees paid in an active, freely competitive market. Financial reporting based on replacement costs basically comes down to the fair value concept. However, an objection may be made here, the value can be rather adequate only for players coming from the secondary market, since the value has been primarily determined upon their use value for a respective club, and often on the basis of yield value. Moreover, the fair value concept in the football industry is based on the use of extremely subjective criteria.

The registration value of players transferred with historical cost would result in an inconsistency in reporting, besides the fact that the historical transfer value has nothing in common with the current replacement value. The registration of some players would be evaluated according to the current replacement value (players brought without transfer), and registration of others (players brought with transfer) according to the historical transfer value. The absurdity of the above-mentioned can be shown in the example of Machester 
United, when Eric Cantona played for the club. Namely, Cantona was brought from Leeds United to Manchester at the transfer fee of $€ 1.8$ million. Therefore, the registration value of this player, who was voted as Manchester United's greatest player by the Inside United magazine in 2001, (Ganguly, 2001) would have been much lower than the accounting value of numerous teammates.

If transfer fees are considered as assets for sale, their devaluation through amortization is excluded. In other words, a potential transfer value, usually would not be diminished, except for players who are about to end their careers. Of course, future transfers will be lowered if a player has previously been overvalued or if his performances decline. This is probably the reason for clubs to opt to present the registration value as current assets. However, the question is what the consequences are if a club fails to sell a player? It turns out that accounting treatment is inappropriate and it is necessary to either recognize the expenditure immediately at the time when the player is transferred, which would be in line with the conservatism principle, or to capitalize this value with the write-off during the contract period, which would be in line with the matching principle. The following conclusion can be drawn: the above-mentioned attitude is unacceptable from the aspect of financial reporting.

From another point of view, transfer fees represent an expenditure related to the provision of resources. The cost of registration rights (transfer fees) are known and the effects of investments are expected in the accounting period defined by a contract, so these expenditures are expected to be capitalized and written-off during the contract period. Otherwise, financial results of the accounting period would have been incomparable, i.e. undervalued in the period when players were transferred, and overvaluated in the upcoming accounting period. Logically, non-existing expenditures cannot be activated, i.e. it is not possible to activate non-existing transfer fees for transfers that have not been realized. In other words, it is improper to present the registration of players brought without transfers in financial reports. Even though this is the point of view of regulatory bodies as well, there is still a tendency to present the registration of players who were brought without transfers in financial reports. For example, explaining the thesis on the necessity of financial reporting of the registration value and the player's value, Rowbottom says that the UK Accounting Standards Board suggests that where the acquisition cost is unknown, an asset can be measured according to its 'value to the business'. (Rowbottom, 2002, p.265) Here he notices that this value is generally accepted when it comes to players as replacement costs. Rowbottom supports this by mentioning the fact that the player registration is a necessary condition for professional football clubs, as a going concern principle. However, when a club acquires players without contracts or players from youth clubs, it does not mean that the club lacks information on the transfer value, but it rather means that there is no transfer value, i.e. historical cost of registration.

As mentioned above, the approach to capitalize and write-off transfers during the contract period has been accepted by relevant regulatory bodies. However, this accounting treatment is vigorously criticized. Namely, FRS 10 and IAS 38 require that an intangible asset shall be recognized if it is probable that the expected expenditure will result in economic benefits. It turns out that it is questionable whether acquiring (some) players will increase the club's financial success. Research by Amir and Livne shows that there is a weak relationship between intangibles, i.e. capitalized transfer expenditures and future benefits. (Amir and Livne, 1995, p. 549). It has been concluded that investment in players' contracts is much more connected to incomes than to profitability. In the Report of the UEFA (UEFA, Rapport de benchmarking sur la procédure d'octroi de licence aux clubs, exercise 2011, 04.02.2013. p. 108) it can be seen that operating revenues of football clubs are constantly increased (despite stagnation and recession in European countries), but the growth in incomes is not followed by the growth in profitability. On the contrary, European football clubs have constantly generated increasing losses. In 2001, the first league clubs across Europe discovered a net operating loss in the amount of $€ 388$ million euro, which is the increase in $€ 50$ million euro compared to the previous year. In the same year, the loss that exceeded the capital was manifested in 38\% of clubs (225 clubs). Among these clubs there were 22 out of 77 'elite' clubs. (UEFA, Rapport de benchmarking sur la procédure d'octroi de licence aux clubs, exercice 2011, 04.02.2013. p.108)

Despite all the above-mentioned, the football clubs that operate with loss pay off the agreed transfer fees and salaries, which is inconceivable not only in high-profitable industries but in all other sports (in Europe). There are many reasons for this increase in losses despite the growth in incomes. Certainly, one of the reasons are higher arranged transfers and increasing salaries of players. Gumb and Demoulins-Lebault add the following reasons: (a) motivation of club owners is not often of economic nature, but they buy clubs to enhance the prestige, or for money laundering; (b) players appropriate a great amount of revenues through contractual bonuses; (c) clubs that achieve higher ranking strive to recruit new players or to keep current, and by default increase costs in the medium term, before ensuring revenues to cover these costs. (Gumb \& Demoulins-Lebault, 2010, p.7) 
Apart from the uncertainty about the contribution of players to future economic benefits, the research of Amir and Livne shows that investment in players contracts is positive and significant only for two years maximum, which is considerably shorter than the amortization period. Therefore, the results of the research do not support the requests of IFR 10 and MRS 38 for capitalization. (Amira \& Livne, 2005, p. 552)

However, even if a club operates with profit it is difficult, even impossible, to measure the contribution of individual players. The complexity of the measurement can be illustrated by the case of the Argentinean football player Rodrigues, who made it possible for Marseille to win Coupe de France in 1992 by playing for another club. This had a positive impact on the financial results of Marseille. Namely, Rodriguez, who has played for Toulon, enabled Toulon to defeat Marseille's direct competitor for the Coupe de France. ${ }^{9}$ (Bourgeois, 2007, p. 6-7)

There is some criticism of the treatment of registration amortization. Referring to the works of Epingard, Bourgeois points out that an amortization period should comprise the period when the effects of the player's engagement are present, and not a contractual period. (Epingard, 1999: according to Bourgeois, 2007, p. 8-9) To be precise, revenues of the participation in European clubs are generated by players who played the previous year, and some of them have even left the club. Sometimes a positive impact of a player, especially a star, his advice and experience can be felt for several years after his leave. In 2006, Aulas, the president of FC Lyon, said that Anderson's engagement, (from 1993 to 2006.) and his great contribution are still felt in the club. (According to Bourgeois, 2007, str. 9)

There are some arguments about the above-mentioned procedure, from the point of securing control over the assets. A problem with injuries and players' decision to stop playing even if their contracts did not end should be mentioned here. The problem with injuries could be solved with a proper insurance coverage, although it often happens that a player was not covered by insurance at the time of injury. There is a wellknown case of the Italian football player Padovano who signed a contract with Metz in 2000, and had a severe injury on the first day of training, and whose health insurance policy didn't cover the very first day. (Bourgeois, 2007, p. 8) There is another case of Stéphane Ziani who signed a contract with Ajacco in June 2005, and decided to stop playing football the same year in September. (Bourgeois, 2007, p. 8) As pointed out by Bourgeois, the legislation provides compensation to clubs by players; clubs can claim compensation due to the unfair unilateral termination of the contract by a player. It often happens that the compensation doesn't cover transfer fees. (Bourgeois, 2007, p. 8)

However, as mentioned by Amira and Livne, other findings indicate that market agrees with the treatment provided by FRS10. Their research shows that there is a relationship between transfer fees and the market value of a club. Actually, it is about an anomaly in the football industry. It is usual for football clubs often to have a market value that exceeds their yield value. As mentioned by Borré and Gelmini, football clubs have a significant goodwill value even with poor economic performances. (Borré \& Gelmini, 2008) In the football industry, there is evidence both for negative results/margins and for positive market values, even in clubs operating with loss that exceeds capital. For example, Liverpool FC was sold in 2007 for $€ 197 \mathrm{~m}$ and then sold again in 2010 for $€ 191 \mathrm{~m}$, with accounting value of $€ 53 \mathrm{~m}$ in 2007 and $€ 7 \mathrm{~m}$ loss that has exceeded capital in 2010. Goodwill was estimated $€ 73 \mathrm{~m}$ and $€ 71 \mathrm{~m}$ respectively. (According to UEFA, Rapport de benchmarking sur la procédure d'octroi de licence aux clubs, exercice 2011, 04.02.2013. p.109).

Conclusion

Transfer fees are the second largest expenditure in the football industry, right after salary costs. However, unlike salary costs, which are always expenses of the period, transfer fees can be seen as an investment in asset, if a club has an intention to alienate a player before the end of the contract. It is unpredictable whether capital gains or capital losses will be achieved. Studies conducted in Europe show that, in most cases, players have been sold before the end of their contracts. The sale of players does not necessarily imply that the club will have to pay transfer fees, since a player can be acquired without 
transfer fees, i.e. the club can take over a player who does not have a contract, can renew the contract, or bring a player from a youth club.

Transfer fees are traditionally considered expenses of the period. However, given that the subject matter was not clearly defined in the second half of the twentieth century, except in clubs who involved transfer fee expenses at the moment of players' registration, some clubs have capitalized these fees and presented them as intangible assets, while others presented them as current assets. The enactment of FRS 10 and IAS 38, in the late twentieth century, signified the end of alternative accounting treatment of transfer fees. To be precise, an attitude that requirements for their capitalization were met prevailed, therefore, their recognition and presentation as intangible assets became a mandatory procedure. However, a real question is how the procedure is justified having in mind that it is difficult to determine the contribution of agreed transfer fees to the financial success of clubs where the majority of clubs operate with losses, where players are often alienated before the end of the contract, and requests for control cannot be completely fulfilled.

Controversies about the accounting treatment of the transfer fee are the consequence of numerous uncertainties, which are inherently present in the football industry. In fact, it is uncertain whether a player will be alienated before the end of the contract or not, what his transfer fee will be, whether and to what extent will a player make contribution to sports results, whether the result will have any consequences in the improvement of the financial result, or whether the player will directly make contribution to the financial success of the club. As the consequence of all the above-mentioned uncertainties, all the accounting policies have their weaknesses.

\section{REFERENCES:}

[1] Amira, E., Livne, G. (2005): Accounting, Valuation and Duration of Football Player Contracts, Journal of Business Finance \& Accounting, 32(3) \& (4), April/May 2005, 549-586

[2] Borré, L., Gelmini, L., Goodwill, Negative Margins and Results: Some Evidence from the Professional Football Industry, Eighth International Business Research Conference: Research For Change, Dubai 27-28 mart 2008.

[3] Bourgeois, F., Les joueurs de football peuvent-ils être assimilés à des actifs incorporels?, 28eme congrès de l'Association Francophone de Comptabilité "Comptabilité et environnement", Ateliers doctoraux "jeunes chercheurs", Poitiers 23-27 mai 2007.

[4] Forker, J. (2005): Discussion of Accounting, Valuation and Duration of Football Player Contracts. Journal of Business Finance and Accounting, 32(3/4), 587-598.

[5] Ganguly, A., "Eric and us". Manchester United, Future Publishing, March 2001, 42-48

[6] Gumb, B., Desmoulins-Lebeault, F. (2010) : De la pertinence du capital humain comme objet comptable: le cas des joueurs de football. halshs-00526905, version 1 - 16 Oct 2010. Manuscrit auteur, publié dans "Capital immatériel : état des lieux et perspectives, Montpellier : France

[7] Knežević, S., Stanković, A., Tepavac, R. (2012): Accounting information system as a platform for business and financial decision-making in the company. Management - journal for the theory and practice of management, 17(65), 63-69.

[8] Morrow, S. (1997): Accounting for Football Players. Financial and Accounting Implications of 'Royal Club Liégois and Others V Bosnian' for Football in the United Kingdom, Journal of Human Resource Costing \& Accounting, Vol. 2 Iss: 1, pp.55-71

[9] Morrow, S. The new business of football: Accountability and finance in football, Basingstoke: Macmillan, 1999

[10] Pavlović, V., Mijatović, P., Milačić, S. (2013): Financial Reporting of Football Clubs in R. Serbia, Management - Journal for Theory and Practice Management, vol. 18(67), 55-62.

[11] Pravilnik o licenciranju klubova Fudbalskog saveza Srbije, FUDBAL - Van. broj 6 od 09.11.2012, Fudbalski savez Srbije

[12] Rosdet Nascimento, T. (2012): As 25 maiores transferências mundiais 2010/2011, February 6, 2011: available at http://financefootball.wordpress.com/2011/02/06/as-25-maiores-transferencias-mundiais20102011/

[13] Rowbottom, N. (2002): The application of intangible asset accounting and discretionary policy choices in the UK football industry, British Accounting Review, Vol. 34(4), pp. 335-356.

[14] Rowbottom, N., Intangible asset accounting and accounting policy selection in the football industry, PhD theses, University of Birmingham, 1998 
[15] UEFA, Rapport de benchmarking sur la procédure d'octroi de licence aux clubs, exercice 2011, 04.02.2013.

[16] UEFA, Règlement de I'UEFA sur l'octroi de licence aux clubs et le fair-play financier, Edition 2012, 01 juin 2012

[17] Villemus P., Gur $\square u$, C., The branding and value of sport performers: an analysis of the European football, Cambridge Business \& Economics Conference, Cambridge, UK, June 27-29, 2011

Web page:

www.transfermarkt.de

Receieved: September 2013.

Accepted: January 2014.

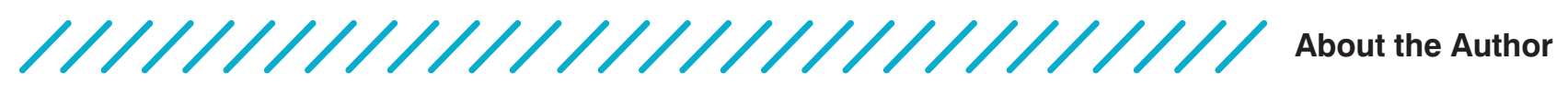

Vladan Pavlović, PhD, Full professor University of Pristina, Faculty of Economics (Kosovska Mitrovica) vladan.pavlovic@pr.ac.rs

Vladan Pavlovic was born on 16th December, 1971 in Belgrade. He received his Bachelor and MSc degrees from the Faculty of Economics in Subotica, and a PhD from the Faculty of Business Studies, Megatrend University, where he was appointed assistant and associate professor in the field of accounting and auditing. He was appointed a full time professor in 2012 at the Faculty of Economics in Pristina (Kosovska Mitrovica). He has published numerous papers in international and national journals

Srećko Milačić, PhD, Full professor University of Pristina, Faculty of Economics (Kosovska Mitrovica) srecko.milacic@pr.ac.rs

Srecko Milačić was born on 12th March, 1965 in Priština. He graduated from the Economics Faculty in Priština with honours. He earned his master's degree at the Faculty of Economics in Belgrade and a PhD at the Faculty of Economics, University of

Priština, where he earned all scientific titles. He was a scholar of the Japanese "Sasakawa" Foundation. In addition to working at the Economics Faculty in Priština, he was hired as an associate at the Institute for Economic Research in Priština and a NICEF associate where he participated in the development of many investment projects and assessments. In the period 2001-2006 he was head of the Department of Finance and Foreign Trade. He was appointed the Chairman of the Council of the Faculty in 2004. Since 2006 he has served as Dean of the Faculty of Economics in two terms. From October 2012 he is the Rector of the University of Priština.

Isidora Ljumović, PhD, Research Associate Economic institute, Belgrade Email: isidora.ljumovic@ecinst.org.rs

Isidora Ljumović was born on 9th of April, 1980 in Zaječar. She graduated from the Faculty of Organizational Sciences, University of Belgrade. She received her MSc from the Faculty of Business Studies, Megatrend University, and a PhD from the Faculty of Economics, University of Niš. She was appointed assistant professor at the Faculty of

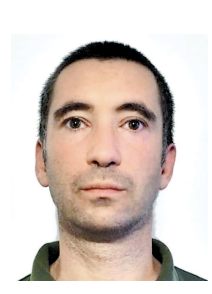

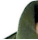

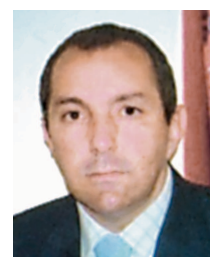

Business Studies, Megatrend University. In 2012 she acquired the title of Research Associate. She has published numerous papers in international and national journals. 